\title{
ANALISIS KUALITAS AIR DAN BEBAN PENCEMARAN AIR PADA SUB DAS BOENTUKA KABUPATEN TIMOR TENGAH SELATAN
}

\author{
Umbu A. Hamakonda ${ }^{1}$, Bambang Suharto ${ }^{2}$, dan Liliya Dewi Susanawati ${ }^{2}$ \\ ${ }^{1}$ Mahasiwa Magister Keteknikan Pertanian, Universitas Brawijaya \\ ${ }^{2}$ Fakultas Teknologi Pertanian, Universitas Brawijaya \\ Email: umbu_hamakonda@yahoo.com
}

\begin{abstract}
Rivers in the Boentuka Sub-watershed of Timor Tengah Selatan Regency have been shown to experience pollution caused by domestic and agricultural activities. This study aims to assess water quality and identify river water pollution loads based on water quality according to Government Regulation Number 82 of 2001 concerning water pollution management and control. The parameters analyzed were physical, chemical, and biological, the length of the river in the Boentuka Sub-watershed was $15 \mathrm{~km}$. The method of river water pollution index from upstream to downstream in 6 sampling points with test parameters such as the biological oxygen demand, chemical oxygen demand, fecal coliform and total coliform in the downstream has exceeded the criteria of class I water quality standards according to PP No. 82 of 2001. Pollution index of 1.11 to 4.62 . This shows that the quality of river water has been polluted with mild pollution status. While the pollution load of domestic waste dumped into the river is on the biological oxygen demand parameter of $6297,584 \mathrm{~kg} /$ day and chemical oxygen demand of $7871.98 \mathrm{~kg}$ / day, fecal coliform pollution load of 458.0108 MPN / day and totalcoli 1210.121 MPN / day.

Keywords-River water quality; Water pollution load
\end{abstract}

\section{PENDAHULUAN}

Air merupakan sumber daya alam yang diperlukan untuk semua makluk hidup. Oleh karena itu sumber daya air tersebut harus dilindungi agar dapat dimanfaatkan dengan baik oleh manusia dan makhluk hidup lainnya. Pemanfaatan air untuk berbagai kepentingan harus dilakukan secara bijaksana denga memperhitungkan kepentingan generasi sekarang dan generasi yang akan datang (Nugroho, 2008). Salah satu sumber air yang banyak dimanfaatkan untuk memenuhi kebutuhan hidup manusia dan makhluk hidup lainnya yaitu sungai. Sungai merupakan ekosistem yang sangat penting bagi manusia. Sungai juga menyediakan air bagi manusia untuk berbagai kegiatan seperti pertanian, industri maupun domestik (Siahaan $d k k$., 2011). Air sungai yang keluar dari mata air biasanya mempunyai kualitas yang sangat baik. Namun dalam proses pengaliran air tersebut akan menerima berbagai macam bahan pencemar yang mengakibatkan air sungai menjadi tercemar (Sofia $d k k$., 2010). Beberapa tahun terakhir ini, kualitas air sungai di Indonesia sebagian besar dalam kondisi tercemar, terutama setelah melewati daerah pemukiman, dan pertanian (Simon dan Hidayat, 2008). Meningkatnya aktivitas rumah tangga, pertanian dan industri akan mempengaruhi dan memberikan dampak terhadap kondisi kualitas air sungai terutama aktivitas rumah tangga yang memberikan masukan bahan pencemar dengan konsentrasi biological oxygen demand (BOD) terbesar ke air sungai (Priyambada $d k k$., 2008).

Air Sungai dikatakan terjadi penurunan kualitas air, jika air tersebut tidak dapat digunakan sesuai dengan kebutuhan peruntukkan air secara normal. Status mutu air adalah tingkat kondisi mutu air yang menunjukan bahwa kondisi air sungai tercemar atau kondisi baik pada suatu sumber air dalam waktu tertentu dengan membandingkan baku mutu air yang ditetapakan menurut PP No 822001 tentang pengelolaan kulaitas air dan pengendalian pencemaran air. Penentuan status mutu air dapat dilakukan dengan menggunakan metode indeks pencemaran air. Indeks pencemaran (IP) ditentukan untuk suatu peruntukan, kemudian dapat di kembangkan untuk beberapa peruntukan bagi seluruh bagian badan air atau sebagian dari suatu sungai (KepMenLH, 2003).

Hasil pengujian Unit Pelayanan Teknis Laboratorium Lingkungan BLH Propinsi NTT (2017) menyatakan bahwa wilayah sungai di Sub daerah aliran sungan Boentuka telah tercemar berbagai limbah jenis limbah sehingga telah mengalami penurunan kualitas air dengan nilai Biological oxygen demand BOD sebesar 3,60 mg/l dan chemical oxygen demand COD sebesar 46,50 mg/l yang berada 
pada diatas ambang batas baku mutu air kelas 1 . Beban pencemaran adalah jumlah suatu unsur pencemar yang terkandung dalam air atau air limbah; Pencemaran air dapat merupakan masalah, regional maupun lingkungan global, dan sangat berhubungan dengan pencemaran udara serta penggunaan lahan tanah atau daratan. Walaupun air merupakan sumber daya alam yang dapat diperbaharui, tetapi air akan dapat dengan mudah terkontaminasi oleh aktivitas manusia untuk tujuan yang bermacam-macam sehingga dengan mudah dapat tercemar (Darmono, 1995).

Tujuan dari penelitian ini adalah menganalisis kualitas air sungai pada Sub daerah aliran sungai Boentuka dan menganalisis beban pencemaran air sungai pada Sub daerah aliran sungai Boentuka Kabupaten Timor Tengah Selatan Propinsi Nusa Tenggara Timur.

\section{METODOLOGI PENELITIAN}

\section{A. Lokasi Peneletian}

Penelitian ini dilaksanakan pada bulan April 2018 sampai dengan bulan Juni 2018 di Kabupaten Timor Tengah Selatan Propinsi Nusa Tenggara Timur yang berada pada koordinat S 9०55'27.64" dan koordinat E $124^{\circ} 10^{\prime} 11.55^{\prime \prime}$ E seperti yang ditunjukkan oleh Gambar 1.
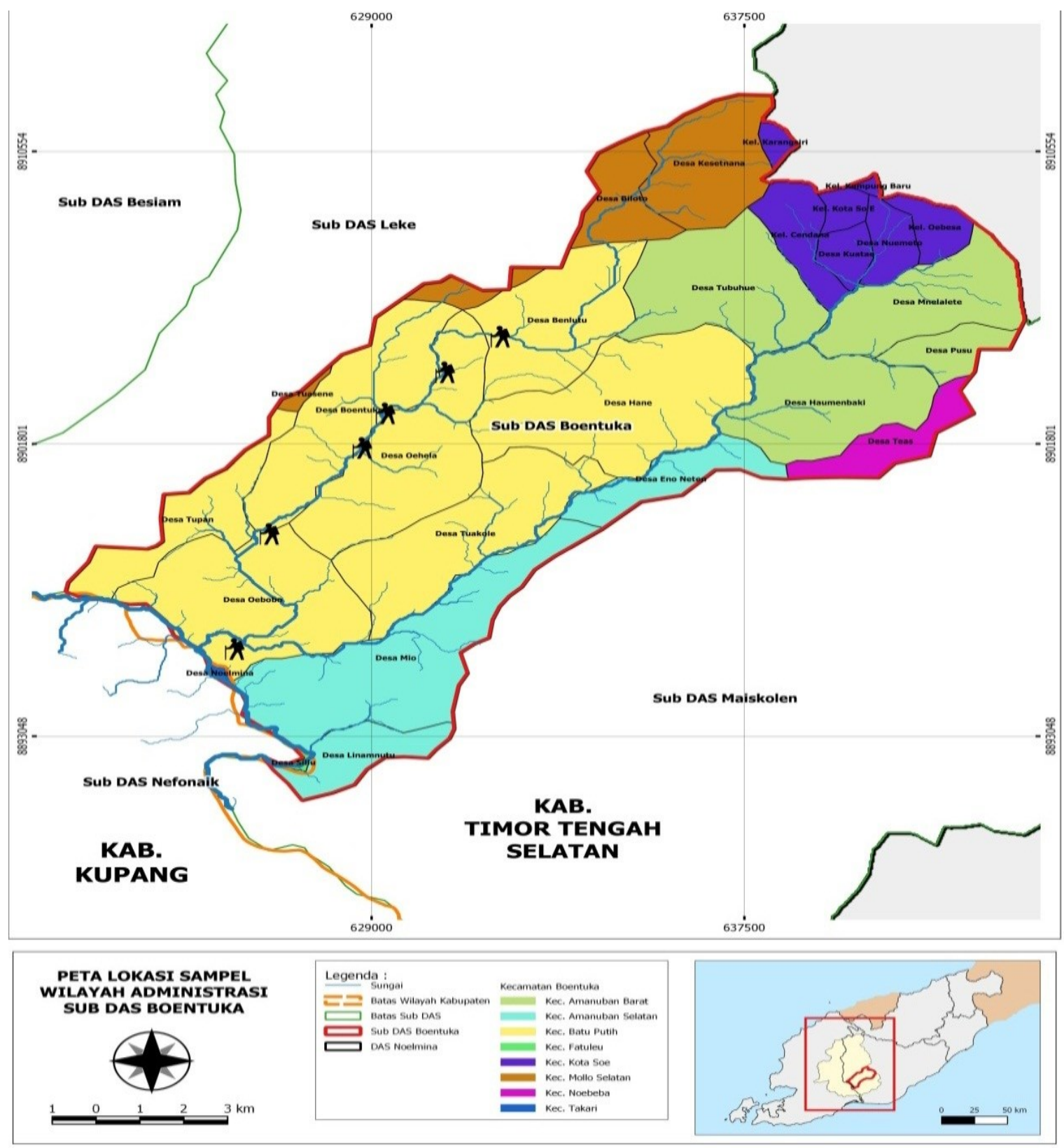

Gambar 1. Peta Lokasi Pengambilan Sampel Air Sungai di Sub DAS Boentuka 


\section{B. Alat dan Bahan}

Alat yang di gunakan ini adalah: Saga GIS, Avenza Maps System, Thermometer, gelas ukur, wadah sampel, Cool Box untuk menyimpan botol yang sudah terisi sampel air sungai, alat pendingin, $\mathrm{pH}$ meter, spektofotometer, $\mathrm{H}_{2} \mathrm{SO}_{4}$, alat titrasi, dan alat pengukur debit (currentmeter). Bahan yang digunakan dalam penelitian adalah data Primer yang diperoleh secara langsung dengan pengambilan sampel air sungai di Sub DAS Boentuka, debit air sungai dan data sekunder yang di peroleh dari BMKG, Balai Wilayah Sungai NTT II, Badan Pengelolaan Daerah Aliran Sungai (BPDAS NTT), dan Badan Pusat Statistik NTT.

\section{Prosedur Percobaan}

Penelitian ini merupakan penelitian deskriptif kuantitatif berbasis laboratorium. Penelitian dilaksanakan pada bulan Mei 2018 sampai dengan selesai, bertempat di Kabupaten Timor Tengah Selatan. Pengambilan sampel air sungai dilakukan secara langsung di badan air yang sedang dipantau dan sampel ini hanya menggambarkan karateristik air pada saat pengambilan sampel (Effendi, 2003). Pengambilan sampel dilakukan sebanyak enam kali ulangan pada wilayah hulu, tengah dan hilir yaitu sampel yang diambil secara langsung dari air sungai kemudian di analisa di laboratorium. Pengujian parameter fisik dilakukan dilapangan sedangkan parameter kimia dan biologi dilakukan di laboratorium. Metode pengujian kualitas air sungai dapat di lihat pada Tabel 1.

Tabel 1. Parameter, Satuan dan Metode Pengujian Air Sungai di Sub DAS Boentuka

\begin{tabular}{|c|c|c|c|}
\hline Parameter & Satuan & Metode & Keterangan \\
\hline \multicolumn{4}{|l|}{ Fisik } \\
\hline Suhu & ${ }^{\mathrm{C}}$ & QI/LKA/12 (Termometri) & Pengujian lapangan \\
\hline TSS & $\mathrm{Mg} / \mathrm{ltr}$ & APHA.2540D,2005 & Pengujian Laboratorium \\
\hline TDS & $\mathrm{Mg} / \mathrm{ltr}$ & APHA.2540D,2005 & Pengujian laboratrium \\
\hline \multicolumn{4}{|l|}{ Kimia } \\
\hline $\mathrm{pH}$ & - & QI/LKA/08 (Elektrometri) & Pengujian lapangan \\
\hline DO & $\mathrm{Mg} / \mathrm{ltr}$ & QI/LKA/02 (Elektrometri) & Pengujian laboratorium \\
\hline COD & $\mathrm{Mg} / \mathrm{ltr}$ & QI/LKA/19 (Spektrofotometri) & Pengujian laboratorium \\
\hline BOD & $\mathrm{Mg} / \mathrm{ltr}$ & APHA.2510 B,- 1998 & Pengujian laboratorium \\
\hline Nitrit & $\mathrm{Mg} / \mathrm{ltr}$ & APHA. 4500 NO2 B, 2005 & Pengujian laboratorium \\
\hline \multicolumn{4}{|l|}{ Biologi } \\
\hline Fecal coliform & MPN/100 & QI/LKA/08 (Tabung Ganda) & Pengujian laboratorium \\
\hline Total coliform & MPN/100 & QI/LKA/08 (Tabung Ganda) & Pengujian laboratorium \\
\hline
\end{tabular}

Data yang telah didapat dari hasil pengujian dari beberapa parameter fisik, kimia dan biologi air sungai, baik itu di lapangan maupun di laboratorium, kemudian dilakukan analisa kualitas air sungai di Sub DAS Boentuka dengan membandingkan baku mutu air kelas I berdasarkan PP No 82 Tahun 2001 tentang Pengelolaan Kualitas Air dan Pengendalian Pencemaran Air. Penentuan status mutu air dengan metode indeks pencemaran. Rumus perhitungan Metode Indeks Pencemaran adalah:

$I P=\frac{\sqrt{\left(\llbracket \frac{C i}{L i j} M\right) \rrbracket^{2}+\left(\frac{C \mathrm{ij}}{\mathrm{Lij}}\right) 2}}{2}$

Keterangan:

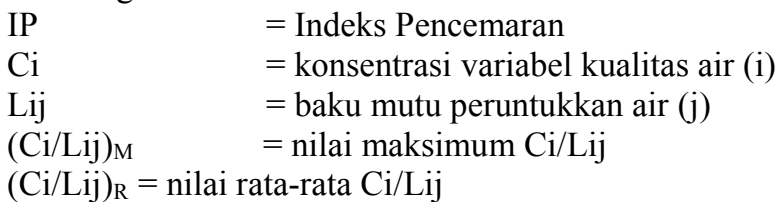

Hasil perhitungan Indeks Pencemaran ini dapat menunjukan tingkat ketercemaran Sungai di wilayah Sub DAS Boentuka dengan membandingkannya dengan baku mutu sesuai kelas air yang ditetapkan berdasarkan Peraturan Pemerintah RI Nomor 82 Tahun 2001. Hubungan nilai indeks pencemaran dengan status mutu air sungai disajikan pada Tabel 2. 
Tabel 2. Hubungan Nilai Indeks Pencemaran dengan Status Mutu Air sungai

\begin{tabular}{cc}
\hline Indeks Pencemaran & Status Mutu Air Sungai \\
\hline $0 \leq \mathrm{PIj} \leq 1,0$ & Kondisi baik \\
$1,0<\mathrm{PIj} \leq 5,0$ & Cemar ringan \\
$5,0<\mathrm{PIj} \leq 10$ & Cemar sedang \\
$\mathrm{PIj}>10,0$ & Cemar berat \\
\hline
\end{tabular}

Beban pencemaran adalah jumlah suatu unsur pencemar yang terkandung dalam air sungai atau air limbah. Menurut Peraturan Menteri Negara Lingkungan Hidup Nomor 1 Tahun 2010 tentang Tata Laksana Pengendalian Pencemaran Air. Cara perhitungan beban pencemaran didasarkan atas pengukuran debit air sungai dan konsentrasi limbah yang di buang ke sungai berdasarkan persamaan (Mitsch \& Goesselink (1993) dalam Lampiran II Peraturan Menteri Negara Lingkungan Hidup Nomor 1 Tahun 2010)):

$\mathrm{BPs}=\mathrm{Qs} \times \mathrm{Cs}(\mathrm{j}) \times \mathrm{f}$.

Keterangan:

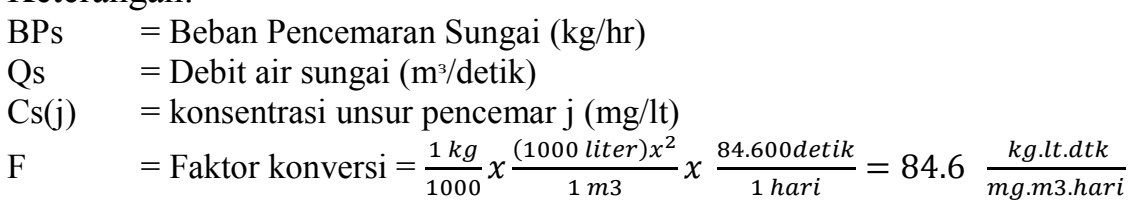

Beban pencemaran adalah jumlah suatu unsur pencemar yang terkandung dalam air atau air limbah. Menurut Peraturan Menteri Negara Lingkungan Hidup Nomor 1 Tahun 2010 tentang Tata Laksana Pengendalian Pencemaran Air. Menurut Peraturan Pemerintah No. 82 Tahun 2001, beban pencemaran adalah jumlah suatu pencemar yang terkandung dalam air atau air limbah.

\section{HASIL DAN PEMABAHASAN}

Analisis kualitas air dilakukan untuk mengetahui kesesuaian air untuk peruntukan tertentu dengan membandingkan dengan baku mutu air sesuai kelas air. Berdasarkan peruntukannya, Sungai Boentuka merupakan golongan air kelas I, maka hasil pemantauan parameter fisika (suhu, TDS dan TSS), kimia ( $\mathrm{pH}, \mathrm{DO}, \mathrm{COD}, \mathrm{BOD}$, nitrit) dan bioologi (fecal coliform dan total coliform) pada masingmasing lokasi pengamatan dalam penelitian ini, selanjutnya dibandingkan dengan baku mutu air kelas I yang terdapat pada Peraturan Pemerintah Nomo 82 Tahun 2001 tentang pengelolaan kualitas dan pengendalian pencemaran air. Hasil analisa terhadap masing - masing parameter adalah gambar dan Tabel 3.

Tabel 3. Variabel Pengamatan Dibandingkan dengan Baku Mutu Air Sungai pada Sub DAS Boentuka

\begin{tabular}{|c|c|c|c|c|c|c|c|c|c|}
\hline \multirow{3}{*}{ Variabel } & \multicolumn{6}{|c|}{ Hasil pengamatan pada setiap } & \multirow{3}{*}{ Satuan } & \multirow{3}{*}{ Acuan Me tode } & \multirow{3}{*}{ Baku Mutv } \\
\hline & & Loka & pengan & bilan sa & npel air & & & & \\
\hline & 1 & 2 & 3 & 4 & 5 & 6 & & & \\
\hline $\mathrm{pH}$ & 8.25 & 8.70 & 8.50 & 8.70 & 8.30 & 8.40 & - & SNI 06-6989.11-2004 & $6-9$ \\
\hline TDS & 148.5 & 149 & 169 & 169.5 & 248 & 250 & $\mathrm{Mg} / \mathrm{L}$ & SNI 06-6989.11-2005 & - \\
\hline DO & 70 & 69.7 & 70 & 73 & 66.1 & 75 & $\mathrm{Mg} / \mathrm{L}$ & SNI 06-6989.14-2004 & 6 \\
\hline $\mathrm{BOD}$ & 1.9 & 2.3 & 1.90 & 1.80 & 3.30 & 2.60 & $\mathrm{mg} / \mathrm{L}$ & SNI $6989.72: 2009$ & 2 \\
\hline $\mathrm{COD}$ & 2.16 & 8.06 & 3.69 & 8.92 & 10.3 & 8.32 & $\mathrm{mg} / \mathrm{L}$ & SNI $6989.2: 2009$ & 10 \\
\hline TSS & 13 & 14 & 30 & 80 & 70 & 30 & $\mathrm{mg} / \mathrm{L}$ & SNI 06-6989.3 2004/Gravimetri & 50 \\
\hline Nitrit & 0.001 & $<\mathrm{MDL}$ & 0.002 & 0.001 & 0.003 & 0.002 & $\mathrm{mg} / \mathrm{L}$ & SNI 06-6989.9-2004 & 0,06 \\
\hline Fecal Coli" & 170 & 170 & 230 & 170 & 480 & 2.800 & $\mathrm{jmL} / 100 \mathrm{~mL}$ & APHA 9221 Tahun 2005 & 100 \\
\hline Total Coli & 230 & 220 & 460 & 490 & 5400 & 3500 & $\mathrm{jmL} / 100 \mathrm{~mL}$ & APHA 9221 Tahun 2005 & 1000 \\
\hline
\end{tabular}

Sumber: Pengolahan data analisis laboratorium (2018)

Berdasaarkan hasil analisis di laboratorium di atas menunjukan bahwa parameter oksigen terlarut tertinggi sebesar $75 \mathrm{mg} / \mathrm{L}$, terendah sebesar $66.10 \mathrm{mg} / 1$, parameter BOD tertinggi sebesar $3.60 \mathrm{mg} / \mathrm{L}$, terndah sebesar $1.80 \mathrm{mg} / \mathrm{L}$, fecal coliform tertinngi sebesar 2800 jumlahl $/ 100 \mathrm{ml}$ dan total coliform tertinggi sebesar $3500 \mathrm{jumlah} / \mathrm{ml}$, dari hasil analisis dapat simpulkan bahwa kondisi kualitas air sungai 
Boentuka hulu masih di bawah baku mutu namun di wilayah tengah dan hilir telah melebihi baku mutu air berdasarkan PP Nomor 82 Tahun 2001, hal ini disebabkan karena pada wilayah tengah dan hilir mendominasi aktivitas permukiman yang membuang limbah ke sungai dan aktivitas pertanian yang menggunakan pupuk pada tanaman, jika dilihat dari semua parameter maka parameter biologi air yang paling tinggi yang di tandai dengan nilai fecal coliform dan total coliform.

\section{A. Suhu}

Hasil pengukuran dan pengamatan terhadap parameter suhu di lokasi penelitian mulai dari titik pengambilan 1 sampai dengan titik 6 dengan suhu rata - rata air sungai sebesar $25-33^{\circ} \mathrm{C}$. Berdasarkan hasil penelitian dan pemantauan parameter suhu air Sungai di Sub DAS Boentuka pada masing-masing titik pengamatan menunjukan bahwa tidak terjadi perbedaan yang besar atau relatif stabil yang berkisar antara $25-33^{\circ} \mathrm{C}$ (Gambar 2).

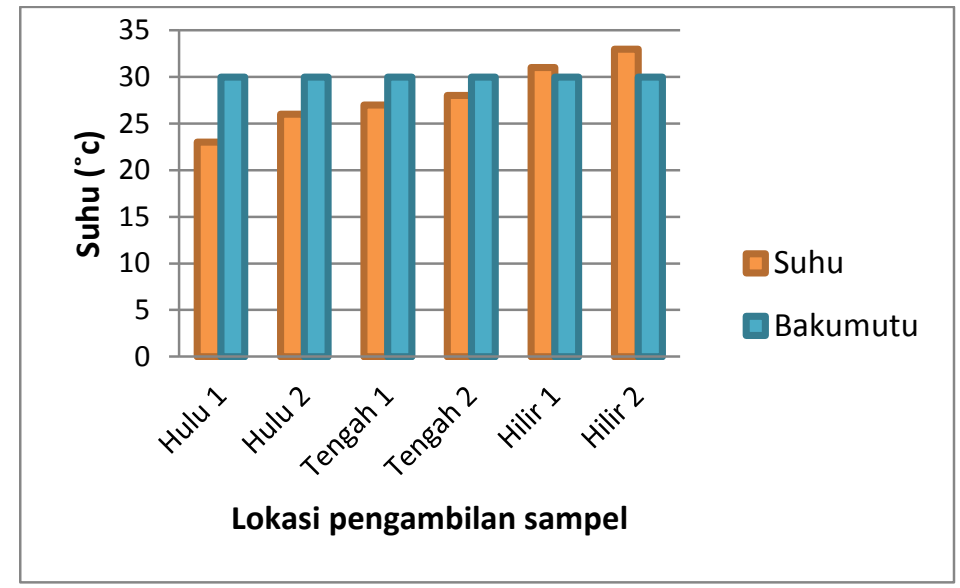

Gambar 2. Hasil Sebaran Suhu Air Sungai

Dibandingkan dengan baku mutu air kelas I berdasarkan PP No. 82 Tahun 2001 yaitu deviasi 5,6 dari keadaan alamiah, maka kondisi kualitas air sungai ditinjau dari parameter suhu masih dalam batas baku mutu air sesuai peruntukannya. Suhu sangat berperan mengendalikan kondisi ekosistem perairan. Peningkatan suhu juga menyebabkan terjadinya peningkatan dekomposisi bahan organik oleh mikroba. Kisaran suhu optimum bagi pertumbuhan fitoplankton di perairan adalah $20^{\circ} \mathrm{C}-30^{\circ} \mathrm{C}$ (Effendi, 2003).

\section{B. TDS (Total Disolved Solid)}

Hasil pengamatan dan analisis terhadap parameter TDS di lokasi penelitian mulai dari titik pengambilan 1 sampai dengan titik 6 dapat di lihat pada Gambar 3. Berdasarkan hasil, sebaran parameter total disolved solid berkisar $145.5-250 \mathrm{mg} / \mathrm{L}$ artinya air tersebut masih layak di minum oleh masyarakat yang berada di wilayah tersebut.

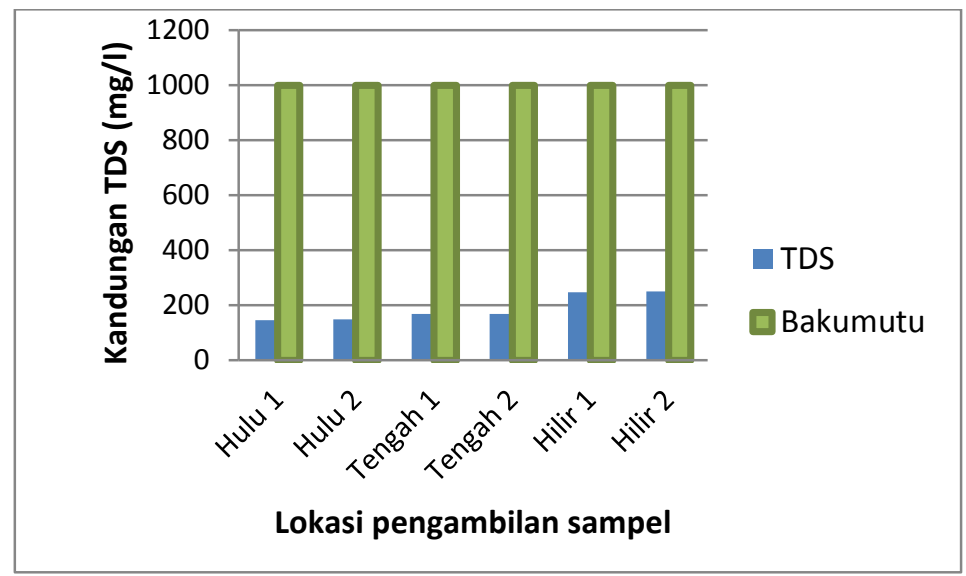

Gambar 3. Hasil Pemantauan Nilai Total Disolved Solid 
Kandungan total disolved solid pada semua titik pantau baik di hulu, tengah dan hilir sungai di Sub DAS Boentuka masih berada di bawah ambang batas baku mutu air kelas 1. Baku mutu kadar total dissolved solid untuk kualitas air kelas 1 berdasarkan Peraturan Menteri Lingkungan Nomor 82 Tahun 2001 adalah sebesar $1000 \mathrm{mg} / \mathrm{l}$. Hal ini sejalan dengan penelitian menurut Fardiaz (1992) menyatakan bahwa padatan terlarut adalah padatan - padatan yang mempunyai ukuran - ukuran lebih kecil dari padatan tersuspensi.

\section{Total Suspended Solid/ Padatan Tersuspensi (TSS)}

Hasil pengamatan dan analisis terhadap sebaran parameter TSS di lokasi penelitian mulai dari titik pengambilan sampel 1 sampai dengan titik sampel 6 dapat di lihat pada Gambar 4. Hasil analisa padatan tersuspensi menunjukkan bahwa Total Suspended Solid berkisar antara 13-80 mg/1. Parameter padatan tersuspensi telah melebihi ambang batas baku mutu air menurut Peraturan Pemeritah Nomor 82 tahun 2001, dimana baku mutu air kelas I tidak memenuhi syarat bahwa padatan tersuspensi dalam air sungai maksimal $50 \mathrm{mg} / \mathrm{L}$. Padatan tersuspensi merupakan padatan yang dapat menyebabkan kekeruhan dalam air, tidak terlarut dan tidak dapat mengalami pengendapan secara langsung pada air sungai (Fardiaz, 1992).

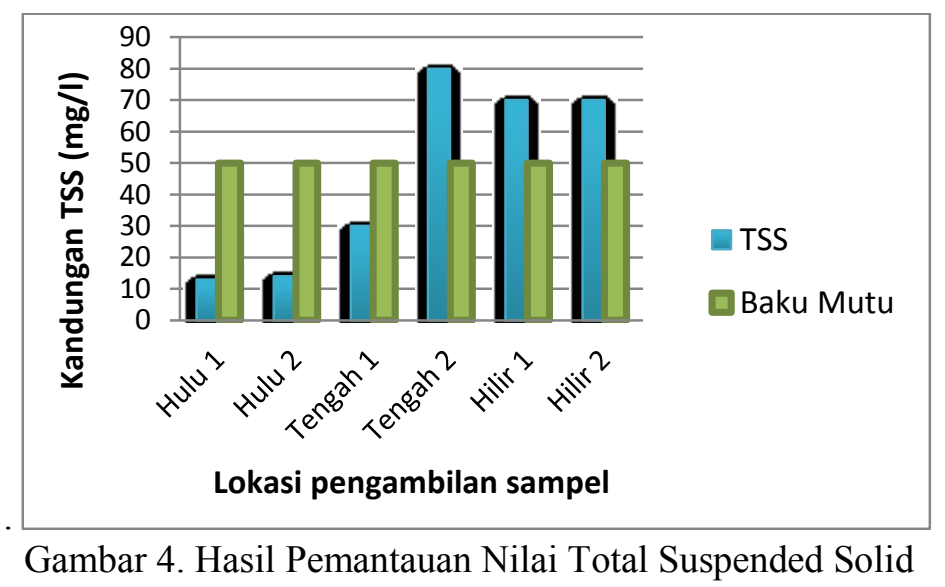

\section{D. pH (Derajat Keasaman)}

Hasil pengamatan dan analisis terhadap sebaran parameter keasman di lokasi penelitian mulai dari titik pengambilan sampel 1 sampai dengan titik sampel 6 dapat di lihat pada Gambar 5. Hasil pengukuran $\mathrm{pH}$ air Sub DAS Boentuka menunjukkan $\mathrm{pH}$ air dari titik 1 sampai titik 6 berada pada kondisi normal yaitu mempunyai nilai $\mathrm{pH}$ 7. Parameter derajat keasaman tersebut masih berada dalam ambang batas baku mutu air sungai kelas I sampai dengan kelas IV menurut Peraturan Pemerintah Nomor 82 Tahun 2001 yang mensyaratkan $\mathrm{pH}$ air berkisar antara $6-9$ untuk kelas I sampai dengan III dan 5 - 9 untuk air sungai kelas IV. Derajat keasaman $(\mathrm{pH})$ air menunjukkan keberadaan ion hidrogen di dalam air. Hal ini dikarenakan ion hidrogen bersifat asam. Sebagian besar biota akuatik sensitif terhadap perubahan $\mathrm{pH}$ dan menyukai nilai $\mathrm{pH}$ sekitar 7 - 8.5 (Effendi, 2003).

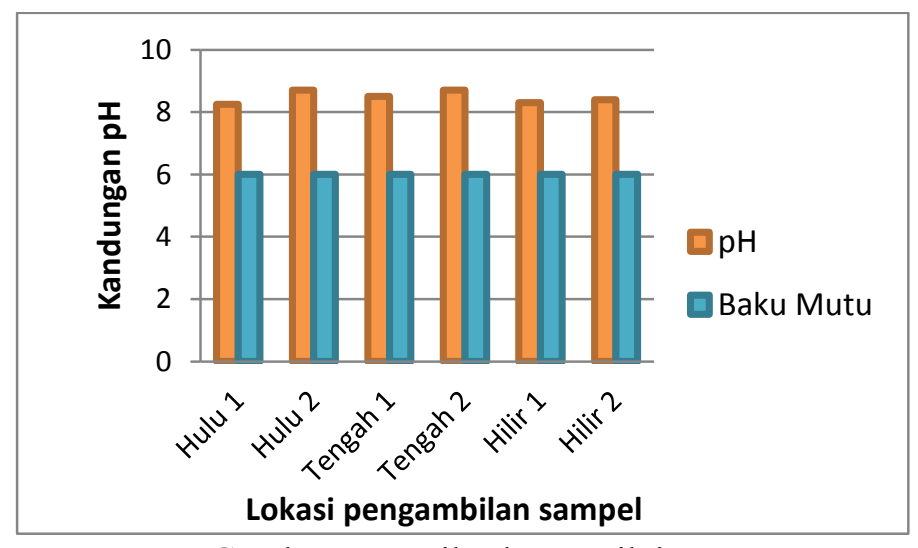

Gambar 5. Hasil sebaran nilai $\mathrm{pH}$ 


\section{E. Disolved Oxigen/Oksigen Terlarut (DO)}

Hasil pengamatan dan analisis terhadap sebaran parameter oksigen terlarut di lokasi penelitian mulai dari titik pengambilan sampel 1 sampai dengan titik sampel 6 dapat di lihat pada Gambar 6 . Hasil pengukuran kadar oksigen terlarut air sungai di Sub DAS Boentuka di lokasi titik pengambilan sampel 1 sampai dengan titik 6 menunjukkan bahwa nilai oksigen terlarut berkisar antara $66.10-70 \mathrm{mg} / \mathrm{l}$. Konsentrasi oksigen terlarut tersebut telah melebuhi baku mutu air sungai kelas I. Baku mutu kadar oksigen terlarut yang dicantumkan merupakan angka batas minimum. Pada daerah perairan tawar, kadar oksigen terlarut berkisar antara $15 \mathrm{mg} / 1$ pada suhu $0^{\circ} \mathrm{C}$ dan $8 \mathrm{mg} / 1$ pada suhu $25^{\circ} \mathrm{C}$ (Effendi 2003).

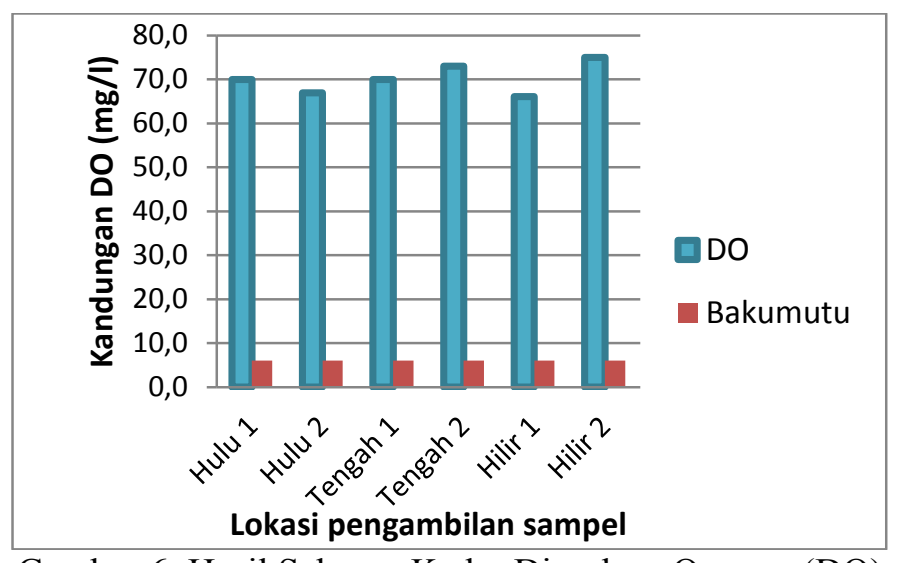

Gambar 6. Hasil Sebaran Kadar Dissolves Oxygen (DO)

\section{F. Biological Oxigen Deman / Kebutuhan Biologi (BOD)}

Hasil pengamatan dan analisis terhadap sebaran parameter BOD di lokasi penelitian mulai dari titik pengambilan sampel 1 sampai dengan titik sampel 6 dapat di lihat pada Gambar 7. Berdasarkan hasil analisa biological oxygen demand air sungai di Sub DAS Boentuka dari titik 1 sampai dengan titik 6 menunjukkan bahwa nilai Biological Oxygen Demand berkisar antara 2-3.60 mg/l. Konsentrasi biological Oxygen Ddemand di titik 2,5, dan 6 telah melampaui nilai ambang batas mutu air sungai kelas I Menurut PP Nomor 81 Tahun 2001 tentang pengelolaan air pengendalian pencemaran. Nilai BOD dari hulu ke hilir cenderung fluktuatif. Hal ini disebabkan aktivitas rumah tangga yang membuang air limbah ke sungai yang menyumbang beban pencemaran bahan organik ke sungai. Perairan yang memiliki nilai BOD lebih dari $10 \mathrm{mg} / \mathrm{L}$ dianggap telah mengalami pencemaran (Effendi, 2003).

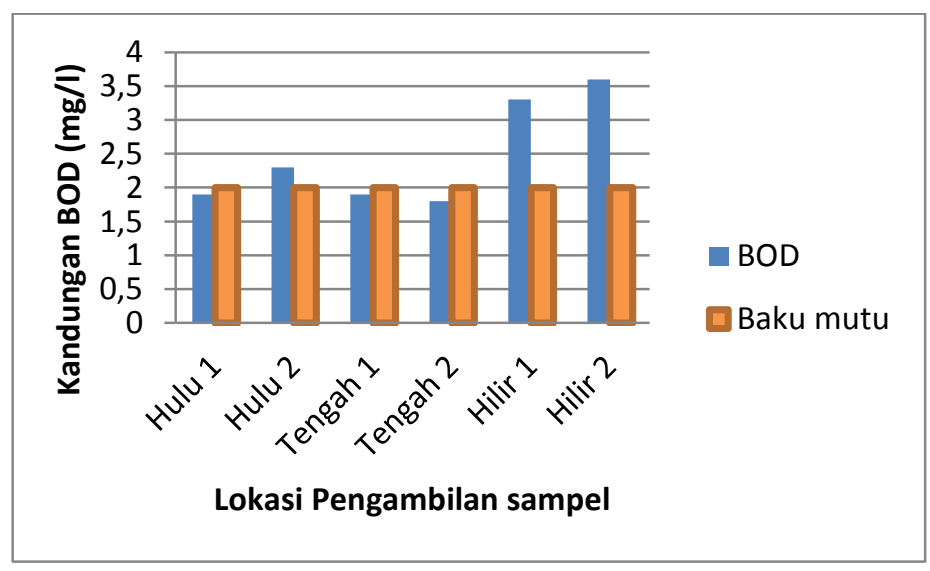

Gambar 7. Hasil Sebaran Nilai Biological Oxygen Demand

\section{G. Chemical Oxigen Demand / Kebutuhan oksigen Kimia (COD)}

Hasil analisis sebaran parameter chemical oxygen demand (COD) menunjukkan jumlah oksigen yang dibutuhkan untuk mengoksidasi bahan organik secara kimiawi, baik yang dapat didegradasi secara biologis maupun yang sukar didegradasi secara biologis. Sebaran parameter chemical oxygen demand (COD) dapat di lihat pada Gambar 8. 


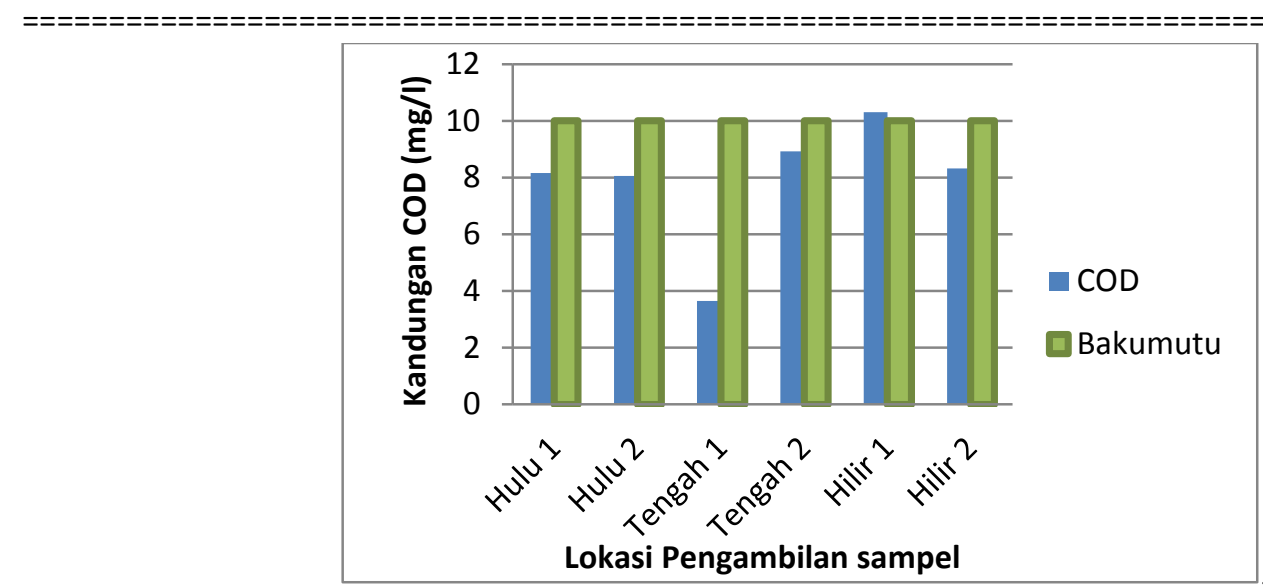

Gambar 8. Hasil Sebaran Kadar Chemical Oxygen Demand

Hasil analisa parameter chemical oxygen demand air sungai di Sub DAS Boentuka dari titik 1 sampai dengan titik 6 berkisar antara 2.16-10.30 mg/l. Konsentrasi chemical oxygen demand dari hulu ke hilir cenderung mengalami kenaikan. Tingginya konsentrasi chemical oxygen demand berkaitan dengan keberadaan bahan organik dalam air. Pada wilayah tengah (pengambilan sampel titik 4,) konsentrasi chemical oxygen demand mengalami peningkatan bila dibandingkan dengan dengan titik 2 dan titik 6. Hal ini berkaitan dengan aktivitas masyarakat yang menggunakan air sungai di Sub DAS Boentuka sebagai tempat mandi, cuci dan buang air besar. Aktivitas masyarakat tersebut menyebabkan peningkatan bahan organik dalam air sungai. Konsentrasi chemical oxygen demand tertinggi terjadi di bagian hilir yaitu pada titik pengambilan sampel 5 setelah industri rumah tangga yang mencapai 10.30 $\mathrm{mg} / \mathrm{l}$.

\section{H. Nitrit ( $\left.\mathrm{NO}_{2}\right)$}

Hasil analisa laboratorium dan sebaran kadar Nitrit $\left(\mathrm{NO}_{2}-\mathrm{N}\right)$ di lokasi penelitian mulai dari titik 1 sampai dengan titik 6 pengambilan sampel air sungai di Sub DAS Boentuka kadar $\mathrm{NO}_{2}$ dapat dilihat pada Gambar 9. Hasil pengukuran kadar nitrit $\left(\mathrm{NO}_{2}-\mathrm{N}\right)$ dalam air sungai Sub DAS Boentuka menunjukkan bahwa konsentrasi nitrit dari titik 1 sampai titik 6 berkisar antara 0,001-0,003 mg/l. Konsentrasi nitrit tersebut masih memenuhi kriteria mutu air sungai kelas I.

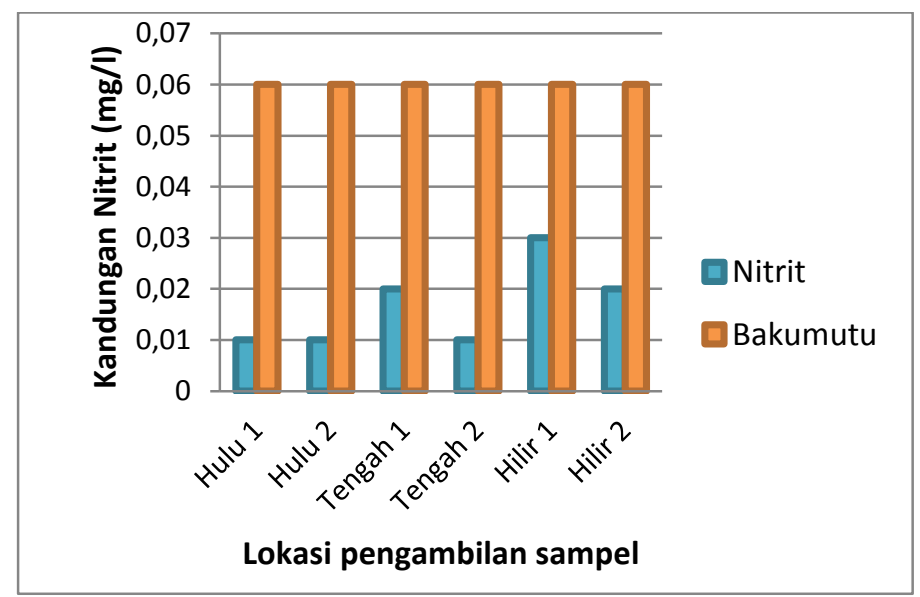

Gambar 9. Hasil Sebaran Kadar Nitrit $\left(\mathrm{NO}_{2}\right)$

Menurut Effendi (2003) kadar nitrit pada perairan sungai boentuka relatif kecil, lebih kecil daripada nitrat, karena segera dioksidasi menjadi nitrat. Sumber nitrit berasal dari limbah pertanian yang menggunakan pupuk anorganik dan limbah rumah tangga yang membuang hasil cucian baik itu lewat resapan maupun di buang secara langsung ke air sungai. Nitrit amat beracun dalam air namun tidak bertahan lama, dari hasil pengukuran variabel nitrit pada air sungai di Sub DAS Boentuka diperoleh hasil yang berada di bawah baku mutu $0,06 \mathrm{mg} / \mathrm{L}$ PP nomor 82 tahun 2001. 


\section{Fecal coliform}

Hasil analisa laboratorium dan sebaran kadar fecal coliform pada lokasi pengambilan sampel air sungai di sub DAS Boentuka dari titik 1 sampai dengan titik 6 dapat dilihat pada Gambar 10. Hasil pengukuran bakteri fecal coliform air sungai di Sub DAS Boentuka menunjukkan bahwa jumlah bakteri fecal coliform per $100 \mathrm{ml}$ air sungai berkisar antara 170-2800. Bakteri coliform di air sungai di Sub DAS Boentuka di lokasi titik pengambilan sampel 1 sampai dengan 6 telah melebihi baku mutu air kelas I tetapi jumlahnya masih memenuhi kriteria mutu air sungai kelas II.

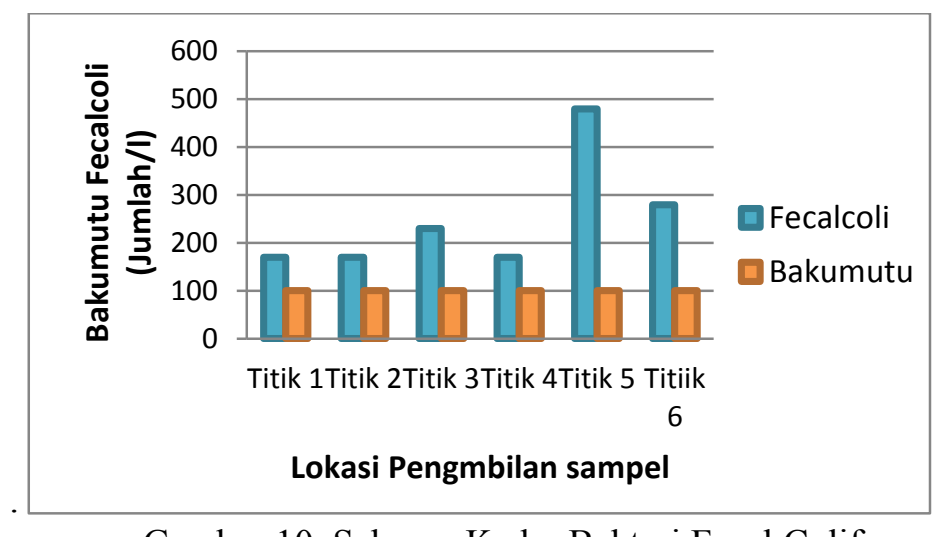

Gambar 10. Sebaran Kadar Bakteri Fecal Coliform

Pada Gambar 10, dapat dilihat jumlah bakteri coliform tertinggi ditunjukkan di bagian hilir yaitu titik pengambilan 6 yang mencapai 2800. Kondisi ini berkaitan dengan aktivitas masyarakat di wilayah tersebut yang menggunakan air sungai sebagai tempat mandi, cuci dan buang air besar terutama di Kecamatan Batu putih, Kecamatan Amanuban selatan. Coliform dapat ditemukan di lingkungan air, di dalam tanah dan pada vegetasi, mereka secara universal hadir dalam jumlah besar di kotoran hewan berdarah panas. Bakteri coliform lainnya berasal dari hewan dan tanaman mati dan disebut coliform nonfecal (Silalahi, 2009). Bakteri coliform lainnya berasal dari hewan dan tanaman mati disebut dengan coliform non fecal coliform (Alaerts dan Santika 1994).

\section{J. Total coliform}

Hasil analisa laboratorium dan sebaran kadar total coliform pada lokasi pengambilan sampel air sungai di sub DAS Boentuka dari titik 1 sampai dengan titik 6 dapat dilihat pada Gambar 11. Hasil pengukuran bakteri Total coliform air sungai di Sub DAS Boentuka menunjukkan bahwa jumlah bakteri total coliform per $100 \mathrm{ml}$ air sungai berkisar antara 220-5400. Parameter bakteri total coliform di Sub DAS Boentuka di lokasi titik pengambilan sampel 1 sampai dengan titik 4, masih memenuhi baku mutu yang telah dipersyaratkan sedangkan pada bagian hilit titik 5 dan 6 telah melebihi kriteria mutu air kelas I tetapi jumlahnya melebihi kriteria mutu air sungai kelas II. Jumlah bakteri total coliform tertinggi ditunjukkan di bagian hilir yaitu titik pengambilan 5 yang mencapai 5400 . Kondisi ini berkaitan dengan aktivitas masyarakat di wilayah tersebut yang menggunakan air Sub DAS Boentuka sebagai tempat mandi, cuci terutama di Kecamatan Batu putih, Kecamatan Amanuban selatan.

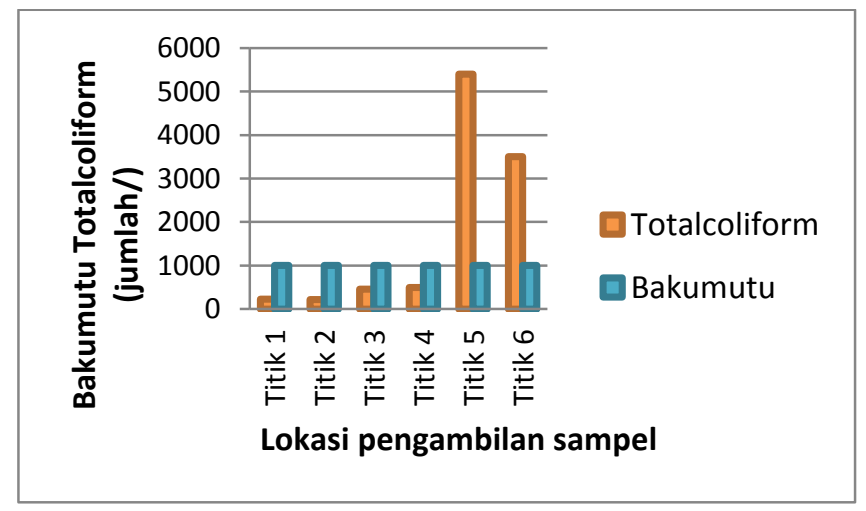

Gambar 11. Hasil Sebaran Kadar Total coliform 


\section{K. Indeks Pencemaran}

Kualitas air sungai merupakan kondisi air yang menunjukkan kandungan makluk hidup, zat, energi atau komponen lain yang ada dalam air. Parameter kualitas air meliputi parameter fisika, kimia dan biologi. Parameter tersebut diukur dengan menggunakan metode tertentu sesuai dengan peraturan perundangan yang berlaku. Parameter fisika meliputi suhu, padatan terlarut, padatan tersuspensi dan daya hantar listrik. Parameter kimia meliputi pH, Chemical Oxygen Demand, Biological Oxygen Demand, Dissolved Oxygen, Nitrit, dan sebagainya. Parameter biologi meliputi keberadaan bakteri coliform. Parameter-parameter tersebut dibandingkan dengan Peraturan Pemerintah Nomor 82 Tahun 2001 tentang Pengelolaan Kualitas Air dan Pengendalian Pencemaran Air untuk selanjutnya dapat mengetahui mutu air sungai. Hasil perhitungan nilai indeks pencemaran sesuai Kep-MENLH Nomor 115 tahun 2003 tentang pedoman penentuan status mutu air dapat dilihat Gambar 12.

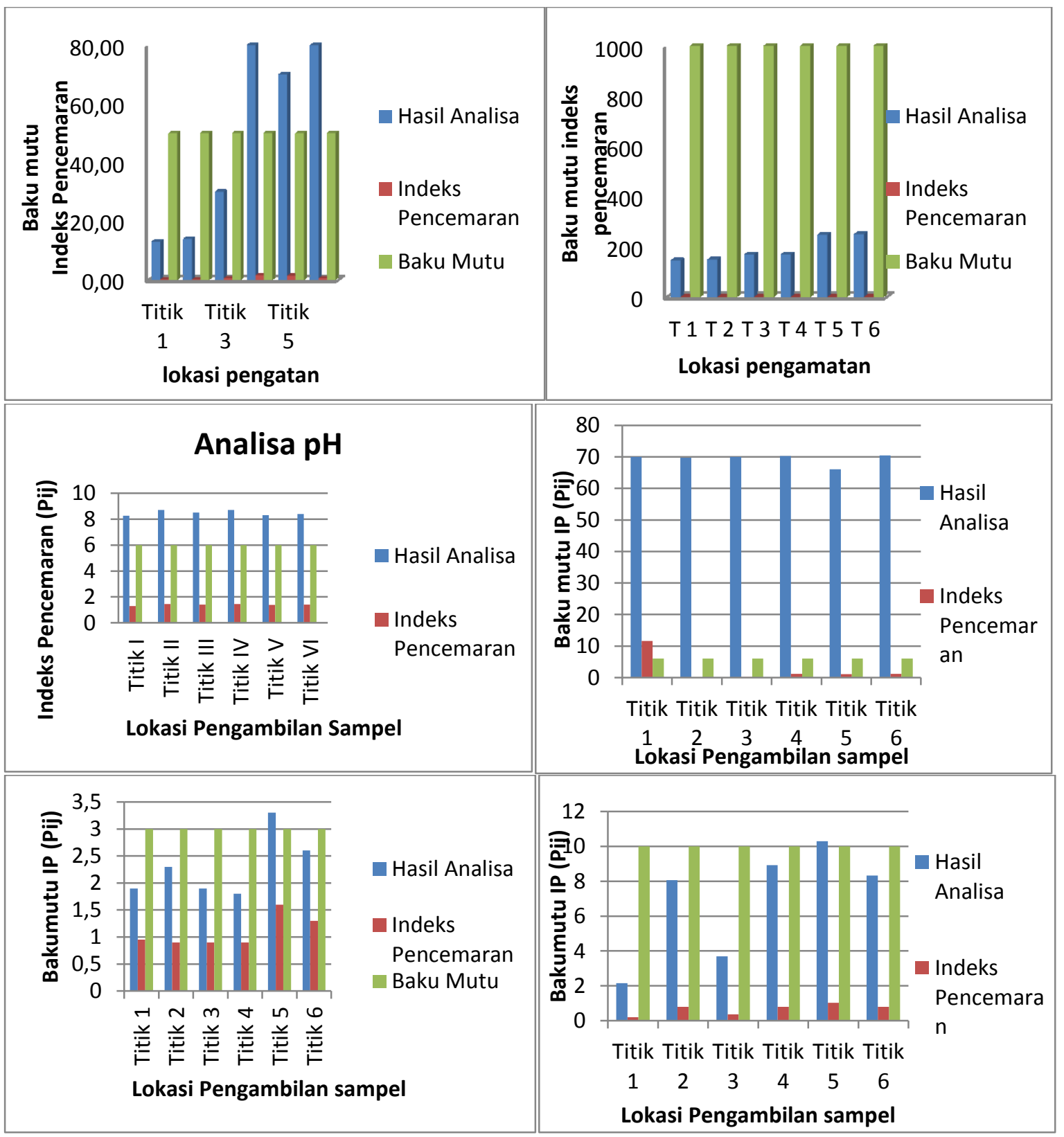

Gambar 12. Hasil Analisa Metode Indeks Pencemaran air sungai

Berdasarkan Hasil analisa status mutu air menggunakan indeks pencemaran menunjukkan bahwa kondisi kualitas air dari sungai di Sub DAS Boentuka pada bulan mei tahun 2018 dapat dikategorikan dengan tercemar ringan dengan nilai indeks pencemaran antara 1-5. Meskipun nilai indeks pencemaran meningkat tetapi masih termasuk dalam kategori tercemar ringan. Tidak signifikan perubahan tingkat 
pencemaran disebabkan karena dalam perhitungan Indeks Pencemaran dilakukan dengan memperhatikan nilai parameter lain selain parameter kimia dan biologi. Sehingga hasil analisa menggunakan indeks pencemaran dapat di katakan bahwa air sungai di sub DAS Boentuka telah tercemar ringan.

\section{Beban pencemaran air sungai di Sub DAS Boentuka}

Beban pencemaran air sungai Sub DAS Boentuka di hitung berdasarkan besarnya konsentrasi masing-masing unsur pencemar dan debit air sungai. Data perhitungan beban pencemaran air sungai di Sub DAS Boentuka disajikan pada Gambar 13.

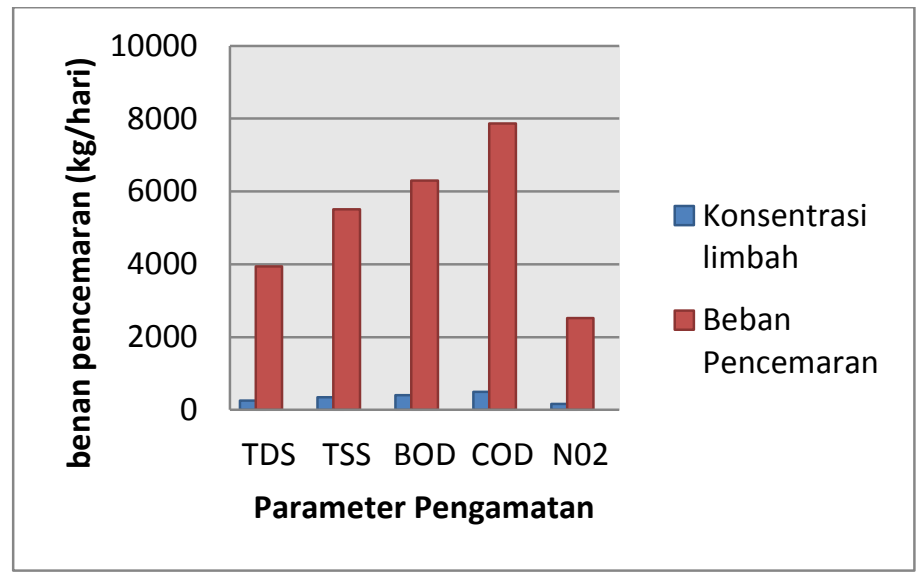

Gambar 13. Beban Pencemaran air sungai

Berdasarkan hasil penelitian dan hasil analisis tentang beban pencemaran pada titik pengambilan sampel II menunjukan bahwa beban pencemaran parameter Total Disolved Solid sebesar 3935,99 $\mathrm{kg} /$ hari, beban pencemaran untuk parameter TSS sebesar 5510,386 kg/hari, beban pencemaran parameter Biological Oxigen Demand sebesar 6297,584 kg/hari, beban pencemaran parameter Chemical Oxigen Demand sebesar 7871,98 kg/hari dan beban pencemaran parameter $\mathrm{NO}_{2}$ sebesar $2519,033 \mathrm{~kg}$ /hari. Parameter yang memberikan beban pencemaran tertinggi terdapat pada parameter Chemical Oxygen Demand 7871,98kg/hari dan Biological Oxygen Demand Sebesar 6297,584 kg/hari sedangkan parameter yang memberikan beban pencemaran terendah terhadap air sungai adalah parameter $\mathrm{NO}_{2}$ dengan beban pencemaran sebesar $2519,033 \mathrm{~kg} / \mathrm{hari}$.

\section{M.Beban Pencemaran Domestik}

Perhitungan Beban pencemaran penduduk merupakan beban pencemaran yang berasal dari aktivitas rumah tangga yang menghasilkan limbah domestik yang merupakan sumber pencemar menyebar (nonpoint source) (WHO, 1993). Beban cemaran domestic disajikan pada Gambar 14.

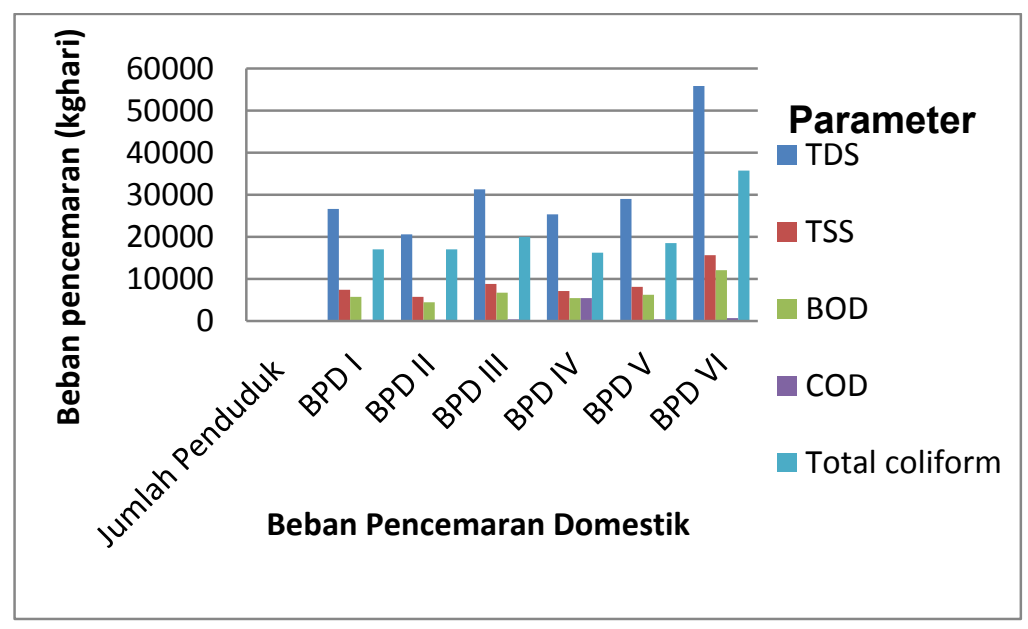

Gambar 14. Beban Pencemaran Domestik 
Berdasarkan hasil perhitungan beban pencemaran penduduk (domestik) dengan dari titik pengambilan sampel I sampai dengan titik VI dari beberapa parameter Total Disolved Solid, Total Suspended Solid, Chemical Oxygen Demand, dan Biological Oxigen Demand menunjukkan bahwa parameter tertinggi Total Disolved Solid dari beberapa titik pengambilan terdapat pada titik VI sebesar $55840.28 \mathrm{~kg} /$ hari, parameter total dissolved solid terendah terdapat di titik II sbesar $20626.71 \mathrm{~kg} / \mathrm{hari}$, beban pencmaran total suspended solid tertinggi terdapat di titik VI sebesar $15635.28 \mathrm{~kg} / \mathrm{hari}$, beban pencemaran biological oxygen demand tertinggi terdapat di titik VI $12061.50 \mathrm{~kg} / \mathrm{hari}$, beban pencemaran biological oxygen demand terendah terdapat di titik II sebesar $4455.37 \mathrm{~kg} / \mathrm{hari}$, sehingga beban pencemaran tertinggi dari semua titik pengambilan adalah titik VI yang merupakan wilayah hilir dari Sub DAS Boentuka.

\section{KESIMPULAN}

Kondisi kualitas air sungai di Sub DAS Boentuka dari hulu ke hilir secara fisik, kimia dan biologi telah mengalami penurunan kualitas air sungai dengan status tercemar ringan - sedang. Beban pencemaran air sungai di Sub DAS Boentuka tertinggi adalah parameter sebesar bilogical oxygen demand $6297.584 \mathrm{~kg} /$ hari dan beban pencemaran chemical oxygen demand sebesar $7871.98 \mathrm{~kg} / \mathrm{hari}$, beban pencemaran Fecal coliform 458.0108 MPN/Hari dan total coliform 1210.121 MPN/hari. Beban pencemaran aktivitas permukiman tertinggi terdapat pada parameter biological oxygen demand sebesar $6759.86 \mathrm{~kg} / \mathrm{hari}$ dan parameter chemical oxygen demand sebesar $5476.91 \mathrm{~kg} / \mathrm{hari}$.

\section{DAFTAR PUSTAKA}

Alaerts, G and S.S. Santika. 1994. Metode Penelitian Air. Penerbit Usaha Nasional Surabaya.

Badan Lingkungan Hidup Propinsi Nusa Tenggara Timur

Darmono, 1995, Logam Dalam Sistem Biologi Makhluk hidup, 111, 131-134, Universitas Indonesia Press, Jakarta.

Effendi, H. 2003. Telaah Kualitas Air Bagi Pengelolaan Sumber Daya dan Lingkungan Perairan. Penerbit Kanisius. Yogyakarta.

Fardiaz, Srikandi.1992. Polusi dan Udara. Penerbit Kanisius. Yogyakarta.

Mitsch W., J. Gosselink, 1993. Wetlands. In Water Quality Prevention, Identification and Management of Diffuse Pollution. Van Nostrand Reinhold, New York.

Nugroho, 2003, Evaluasi Kualitas Air Sungai Ciliwung DKI Jakarta Melalui Pendekatan Indeks Kualitas Air National Sanitation Foundation, Tesis, Departemen Konservasi Sumber Daya Hutan, Fakultas Kehutanan, IPB, Bogor.

Peraturan Pemerintah RI Nomor 82 Tahun 2001. Tentang Pengelolaan Kualitas Air dan Pengendalian Pencemaran Air.

Peraturan menteri lingkungan hidup nomo 01 Tahun 2003 tentang tata laksana pengendalian pencemran air

Keputusan Menteri Negara Lingkungan Hidup Nomor 115 Tahun 2003 tentang Pedoman Penentuan Status Mutu Air. Kementrian Lingkungan Hidup Republik Indonesia, Jakarta.

Priyambada, I. B., Oktiawan W, dan R.P.E Suprapto. 2008. "Analisa Pengaruh Perbedaan Fungsi Tata Guna Lahan Terhadap Beban Pencemaran BOD Sungai (Studi Kasus Sungai Serayu Jawa Tengah)". Jurnal Presipitasi, 5. 55-62.

Siahaan, R., A. Indawan, D. Soedharma, dan L.B. Prasetyo. 2011. "Kualitas Air Sungai Cisadane, Jawa Barat - Banten". Jurnal Ilmiah Sains, 11. 268-273.

Sofia, Y., Tontowi, dan S. Rahayu. 2010. "Penelitian Pengolahan Air Sungai Yang Tercemar Oleh Bahan Organik". Jurnal Sumber Daya Air, 6. 145-160.

Simon, S.B. dan R. Hidayat. 2008. Pengendalian Pencemaran Sumber Air Dengan Ekoteknologi (Wetland Buatan)". Jurnal Sumber Daya Air, 4. 111-124.

Suprihatin, Suparno, 2013. Teknologi Proses Pengolahan Air, Untuk Mahasiswa dan Praktisi Industri. PT Penerbit IPB Press, Bogor.

World Health Organization. 1993. Rapid Assesment of Sources of Air, Water, and Land Pollution. Genewa, Switzerland. 